(online) $=$ ISSN $2285-3642$

ISSN-L = $2285-3642$

Journal of Economic Development, Environment and People

Volume 9, Issue 2, 2020

URL: http://jedep.spiruharet.ro

e-mail: office jedep@spiruharet.ro

\title{
Investigating the Role of Excellent Model in the Competitive Market with Impact on The Economy
}

\author{
Rahil Asadi ${ }^{1}$ \\ ${ }^{1}$ Business Administration, University of Economic Studies (ASE), Bucharest, Romania
}

\begin{abstract}
Nowadays, gaining competitive advantage depends on the organization's capability of moving towards excellence and superiority in various dimensions. Creating competition with ethical principles means that, with scientific methods and strategic planning step towards strengthening the organization's performance in the competitive market. There are many ways to gain a competitive market advantage and all that needs to be appropriate and under the cultural, political, human, and structural conditions. Between all ways, one of the solutions that are more culturally, humane, and structurally appropriate to the organizational and the local business environment, and in practice, some organizations have proven it to be as a high-value or excellent and standard model, can name a model of E.F.Q.M (EUROPEAN, FOUNDATION, QUALITY, MANAGEMENT).

Research methodology - This paper focuses on a conceptual analysis of the relations among establishing an excellence model in organizations and gaining competitive advantage. Here the EFQM excellence model is considered as a suitable framework for achieving the competitive advantage in the market for the organization. The revision of academic literature and logical analysis are the main methodological tools.

Findings - The study shows that establishing competitive advantage foundations and excellence model in the organization and then evaluate and assessing them based on the components mentioned here, can achieve competitive advantage for the organization in the global scale, and in this sense, it is possible to define relationships and impact between each component of excellent model and those coming from the model on the competitive advantage.
\end{abstract}

Keywords: COMPETITIVE MARKET, COMPETITIVE ADVANTAGE, COMPETITIVE ADVANTAGE STRATEGIES', EXCELLENT MODEL, EFQM, EXCELLENT MODEL IN ORGANIZATION

JEL Classification: 01, 010, O15, F02

How to cite: ASADI, R. (2020). Investigating the Role of Excellent Model in the Competitive Market with Impact on The Economy. Journal of Economic Development, Environment and People , 9 (2)20202, DOI: https://doi.org/10.26458/jedep.v9i2.664

\section{Introduction}

Competitive advantage is one of the components that assurance organizational viability. Gaining a competitive advantage cannot achieve without a plane and randomly rather, organizations should

\footnotetext{
${ }^{1}$ E-mail address: Rahil.Asadi65@yahoo.com
} 


\author{
(online) $=$ ISSN $2285-3642$ \\ ISSN-L = 2285- 3642 \\ Journal of Economic Development, Environment and People \\ Volume 9, Issue 2, 2020 \\ URL: http://jedep.spiruharet.ro \\ e-mail: office jedep@spiruharet.ro
}

move forward with mindful consideration and designing scientific frameworks. Customer-oriented, market-oriented, and market-creation approaches require excellence EFQM models in the organization to improve the existing leadership, strategies, and progress the human resources.

The key question of this study is how the EFQM model can create and gains a competitive advantage in organizations and how excellence models can answer the question of, how an organization is superior in terms of competitive advantage? what goals and objectives it pursues, and what are the criteria governing its behaviours' and practices.?

Today, most countries around the world rely on these models to create a competitive national and regional level that is driving organizations and businesses to excellence, growth, and wealth. This model is a set of methods and tools that are used to evaluate the organization and is also used to move toward organizational excellence, constantly identify areas of improvement, and design to achieve optimal improvements and competitiveness through standardized and experienced models, it saves time. An excellent paradigm model, by focusing on enablers, has created foundations for improvement in different dimensions of the organization and with a systematic approach, it creates dialectical coherence within each approach and, on the other hand, by integrating a suite of enablers, it creates synergy in organizational enables that results in improved employee empowerment, increased quality, and new markets. (Dunning and Boyd, 2003) In this case, the profitability of the organization can be ensured by dominating competitive intelligence, and the strategies leading the organization.

\title{
2. Main concept of competitive advantage
}

In general, competitiveness is a process that every organization strives to do better than others in this way. Achieving the competitive capabilities of the world today has become one of the major challenges of different countries internationally. Competitive advantage is the level of attractiveness of the company bids compared to the competitors of the customers. The competitive factor is the distinction in the characteristics or dimensions of any company that enables it to provide better services to its customers than competitors. In general, the components of the competitive advantage are included: Value creation, Market orientation, Customer satisfaction, Diagnosis of potential, Moving actual power, Motivation, skill-building, Reasonable pricing, Accountability, and Innovation.

\section{Strategies for enhancing the competitive advantage}

There are various ways to gain a competitive advantage in order to organizations to be able to achieve profitability by export orientation. In general, the following strategies can provide a competitive advantage for the organization:

3.1. Creating Competitive Intelligence: Is the one way to gain competitive advantage and boost business internally and externally. To gain a competitive advantage, organizations need to institutionalize competitive intelligence based on figure one.

3.2. Implementing competing strategies in front of the competitors: One way to gain a competitive advantage is to design and execute appropriate strategies for your competitors according to the 


\author{
(online) $=$ ISSN $2285-3642$ \\ ISSN-L = 2285- 3642 \\ Journal of Economic Development, Environment and People \\ Volume 9, Issue 2, 2020 \\ URL: http://jedep.spiruharet.ro \\ e-mail: office jedep@spiruharet.ro
}

needs, suitability, and the condition of competitors. Generally, there are five strategies to gain a competitive advantage and they can be used in different conditions of the organization in facing competitors in the international market. (Table 1)

3.3. Strategic Alliance Method: One of the important mechanisms for gaining competitive advantage and conquering domestic and foreign markets is the strategic alliance. The strategic alliance is a partnership agreement between two or more organizations to achieve the competitive success and seek to improve their performance through shared resources.

Strategic alliances can provide a competitive advantage in many areas for the organization, including:

- Mutual Service Alliance

- Mutual investment

- Participation in the value chain

- Licensing Agreement

Strategic alliance methods at the national and international levels will create a new market within and across borders of a country. Therefore, it is necessary to build internal consistency and build strong internal bases and foundations for implementing the strategic alliance, for this aim the organization needs at First, implement it at the local and internal level and then practice and rectified its weaknesses. And in the end, addressed the strategic alliance at the international level.

\title{
4. The role of the excellent model in the organization:
}

In Today's competitive and global markets, gaining a competitive advantage and exporting the products cannot happen accidentally and overnight. Rather, it requires long-term planning, measurement, and design on different aspects of organizational activities, it can be turned into an excellent organization. Whereas the organization achieved greatness and excellent at various levels and to its all parts, we can expect sustainable exports from the organization. Exports and competition at the international market require support and continuity, and that continuity comes from within the organization. Therefore, it is first necessary to create an excellence organization that results is to improving the quality of the product and service, and is dedicated to providing customer focus will be able to reach the market and sell their product or services with the reasonable price, so that competitive advantage can be achieved.

Accordingly, and considering the importance of implementing an excellent model in the organization, taking into account the following issues:

\subsection{Creation of foundations for the excellent model in the organization}

\subsection{Establishing a model of excellence in the organization}

4.1. In order for the organization to move more towards the profitability, it needs to build the right foundations. (Cowen and Tabarrok, 2013) An excellent model is like a house to build and maintain it, at first the basis and foundations need to be established properly. In general, the basic foundations of an excellent organization seeking to gain a competitive advantage can be stated as follows: 


\author{
(online) $=$ ISSN $2285-3642$ \\ ISSN-L = $2285-3642$ \\ Journal of Economic Development, Environment and People \\ Volume 9, Issue 2, 2020 \\ URL: http://jedep.spiruharet.ro \\ e-mail: office jedep@spiruharet.ro
}

- Consequentialism or result-oriented:

- Customer-oriented

- Leadership and purpose stability

- Management based on processes and priorities

- Staff participation and development

- Development of business association

- Social Responsibility

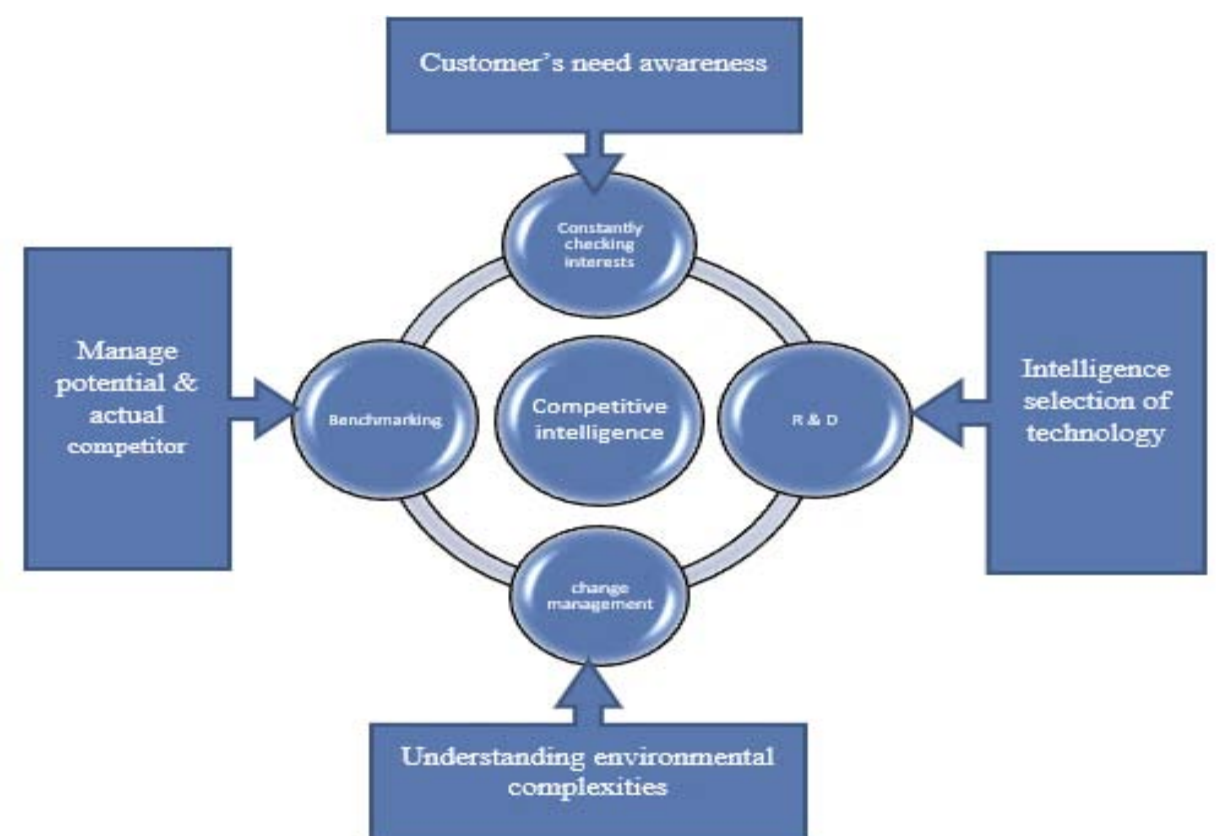

Fig. 1. Competitive intelligence components

\title{
4.2. Establishing and implementing a model of excellence in the organization
}

To establish a business exemplary and excellent model, it is necessary to work in two general areas:

\subsubsection{Creating and provide the empowerment for excellence model}

\subsubsection{Components of excellent model outcome for competitive advantage}

4.2.3. Creating and provide the empowerment for excellence: Majority part of the excellence model It is about empowerment and enablers. Business prosperity and competitive advantage are focus and attention to all of the enablers in the organization, and that is because enablers are involved in producing the products and services, the quality of the product, saving, etc. Paying attention to capabilities can save the organization from stagnation and make it a competitive organization. (Howarth and Greenwood, 2017). 


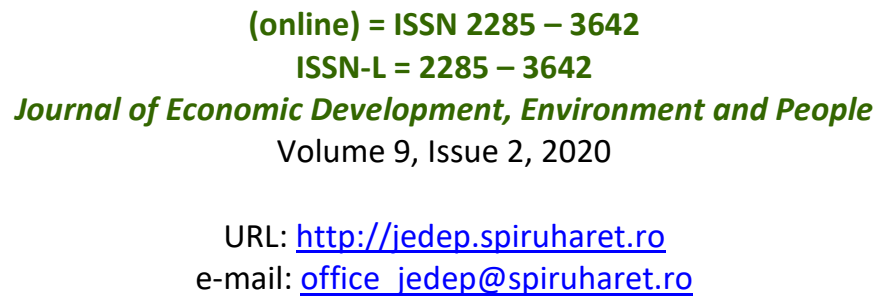

Empowerment components of the EFQM excellent model can provide the platform for business prosperity.

A) Leadership: In this respect, the following actions should be taken as it will be the basis of competitive advantage.

- Leaders determine the values, mission, and aims of the organization and behave according to the excellence model.

- Leaders implement, improve, and develop management systems.

- Leaders have multiple roles, they interact with customers, business partners, and community representatives in an organization.

- Leaders reinforce a culture of excellence in the organization.

- Leaders advocate and supporting the change in the organization.

B) Policy and Strategy. They have the following properties:

- It is based on the present and future needs and expectations of the stakeholders.

- Policies are formulated consciously based on performance evaluation and external comparisons.

- Policies and strategies are implemented in a certain way in the organization.

C) Partnerships and Resources: In this context, the excellence organization in terms of partnerships and resources works in the following way to achieve a competitive advantage.

- Environmental companies are managed

- The company's financial resources are managed

- The assets of the organization are managed

- -Technology is managed in the organization

- $\quad$-skill and knowledge of employees is managed

D) Human resource: plays an important role in profitability must be well-empowered. To gain competitive advantage, human resources, in general, should be treated as follows:

- With planning, human resources can improve sufficiently.

- - Employees' knowledge and creativity have to transform from potential to actual.

- Employee engagement to be used as a development factor.

- Establish a mutual dialogue and relation between staff and managers of the organization.

- -Attention and considering the quality performance of employees in the organization.

Table 1. Five strategies for gaining the competitive advantage

(source: Bell, G. 2002) 


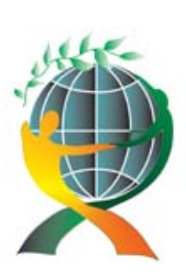

\author{
(online) $=$ ISSN $2285-3642$ \\ ISSN-L = 2285- 3642 \\ Journal of Economic Development, Environment and People \\ Volume 9, Issue 2, 2020
}

URL: http://jedep.spiruharet.ro

e-mail: office jedep@spiruharet.ro

\begin{tabular}{|l|l|l|}
\hline Types of Strategies & Application Time & Solutions \\
\hline Deterrent Strategy & $\begin{array}{l}\text { When identifying the products and } \\
\text { service development's } \\
\text { Sinding customers to organization. } \\
\text { Increase source switching costs for } \\
\text { the client. } \\
\text { Saturation of the distribution duct } \\
\text { Ambiguity of space. } \\
\text { Contrary to the principles and } \\
\text { discipline. }\end{array}$ \\
\hline Shaping Strategy & $\begin{array}{l}\text { When developments cannot be } \\
\text { prevented }\end{array}$ & $\begin{array}{l}\text { Align with developments. } \\
\text { Influencing developments through } \\
\text { investment. } \\
\text { Become a supplier of new } \\
\text { developments. }\end{array}$ \\
\hline Attraction Strategy & $\begin{array}{l}\text { When it is not possible to adapt or } \\
\text { adjust the developments }\end{array}$ & $\begin{array}{l}\text { Bring developments into the } \\
\text { company. } \\
\text { To own the developments, } \\
\text { bipolarize the market. }\end{array}$ \\
\hline Neutralization Strategy & $\begin{array}{l}\text { Discredit goods with new products } \\
\text { through legal means. } \\
\text { Continuous improvement of } \\
\text { technology and products. }\end{array}$ \\
\hline Whiversal & When the developments are deep \\
\hline
\end{tabular}

E) Processes: Processes as a link between all activities of the organization have a great role in empowering and gaining competitive advantage. Therefore, it is necessary to manage the processes of the organization in the following way to profit from their results.

- Designing and managing the processes correctly and creatively

- Reengineering organizational processes based on customer and stakeholder needs.

- Design and develop the product according to customer requirements.

- Timely delivery of products and after-sales service.

- Continuously manage and improve customer relationships with the organization.

4.2.2 Components of excellent model outcome for competitive advantage: working and attention to the empowering and enablers in the organization perfectly, case to the positive result appearing in the organizational performance section. If after paying attention to the enablers the expected results do not achieve, then the organization has not been successful in exporting, profitability, and competitive advantage. Therefore, it is necessary to pay attention to the outcome components of the excellent model and this attention to the components of the outcome model of excellence will lead to the following competitive advantage: 


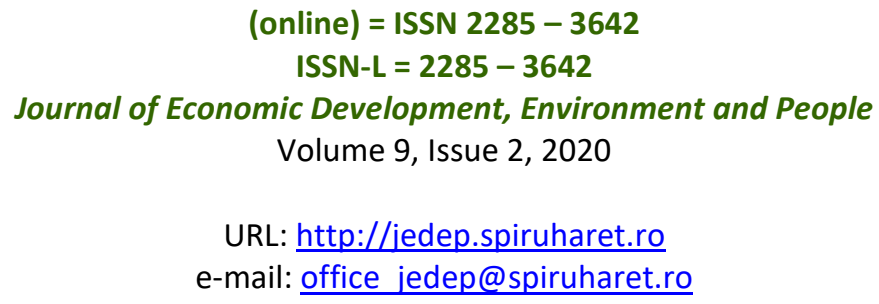

URL: http://jedep.spiruharet.ro

e-mail: office jedep@spiruharet.ro

- Community Results: In this category, community outcomes are measured with two categories of indicators.1- Perceptions indicators such as information dissemination, ethical behaviour, welfare services, etc. 2- Performance indicators such as obtaining a certificate, obtaining a license, and etc.

- Customer results: In this category, the results are also measured by two categories of indicators.1 - Perception indicators such as surveys, responsiveness, and customer relationship. 2- Performance indicators such as customer complaints, customer satisfaction levels.

- Human resource Results: This category is measured by two indicators. 1- Perceptions indices that relate to employees' perceptions of the organization's actions and have a great impact on their satisfaction. Promotion, partnership, leadership, encouragement, and so on. 2Performance indicators relate to all actions taken by the organization with employees, including service delivery, incident measures, etc.

- Key Performance Results: are measured by the following indicators. 1- Key performance benefits such as market financial gains and profitability 2- Key performance indicators such as cash flow, organization costs, etc. 


\author{
(online) $=$ ISSN $2285-3642$ \\ ISSN-L = $2285-3642$ \\ Journal of Economic Development, Environment and People \\ Volume 9, Issue 2, 2020 \\ URL: http://jedep.spiruharet.ro \\ e-mail: office jedep@spiruharet.ro
}
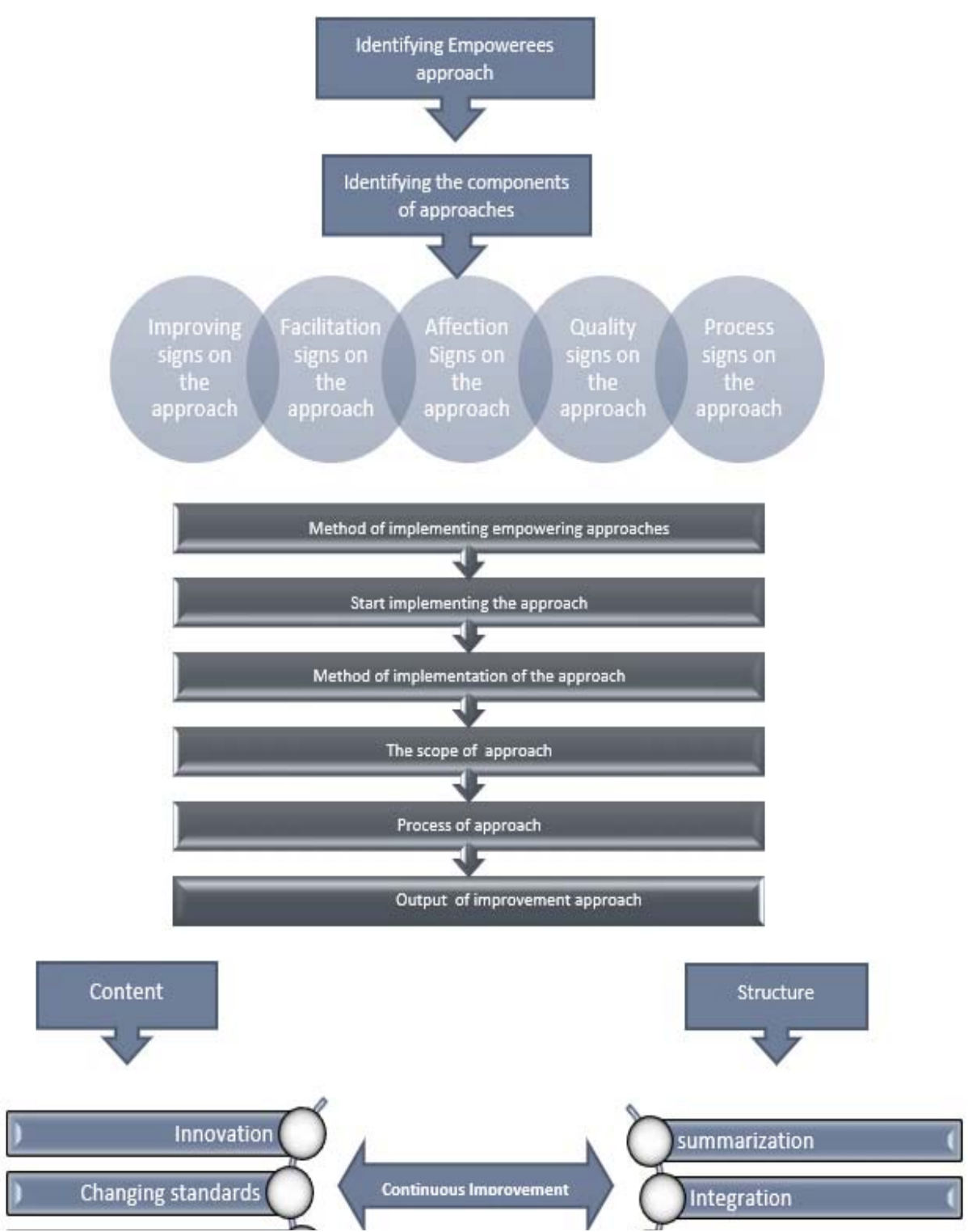

Fig.2. Empowerment Evaluation Components Based on Excellent Model

\title{
4.2.3. Self-Evaluation Model Based on excellence model for the organization
}

Given that evaluating the set of organizational components based on an exemplary excellence model leads to a systematic set of approaches, effective implementation, and improvement of the organization's performance and review of organizational enablers, so we can say it's vital and necessary for any organizations to evaluate themselves. Because the least benefits of the component evaluation or self-evaluations for the organizations are to specifying a set of actions for targeted empowerment foundations and areas of improvement in all sectors. 


\author{
(online) = ISSN $2285-3642$ \\ ISSN-L = 2285- 3642 \\ Journal of Economic Development, Environment and People \\ Volume 9, Issue 2, 2020 \\ URL: http://jedep.spiruharet.ro \\ e-mail: office jedep@spiruharet.ro
}

-Based on the component's evaluation of the organizational model and also based on the excellence model, we can present a hypothetical model in two parts:

A- General Model and Components for the evaluation Performance of the excellence Model: In general, the model and its related components for formatting the evaluation of the set of organizational enablers according to the excellence model. Figure 2.

B- Provide an example of the evaluation model according to the human resources dimension for the organization: A model can be used to evaluate empowerment and outcomes of the organization's components in practice and evaluate the set of approaches and outcomes in a specific format. According to Figure 3.

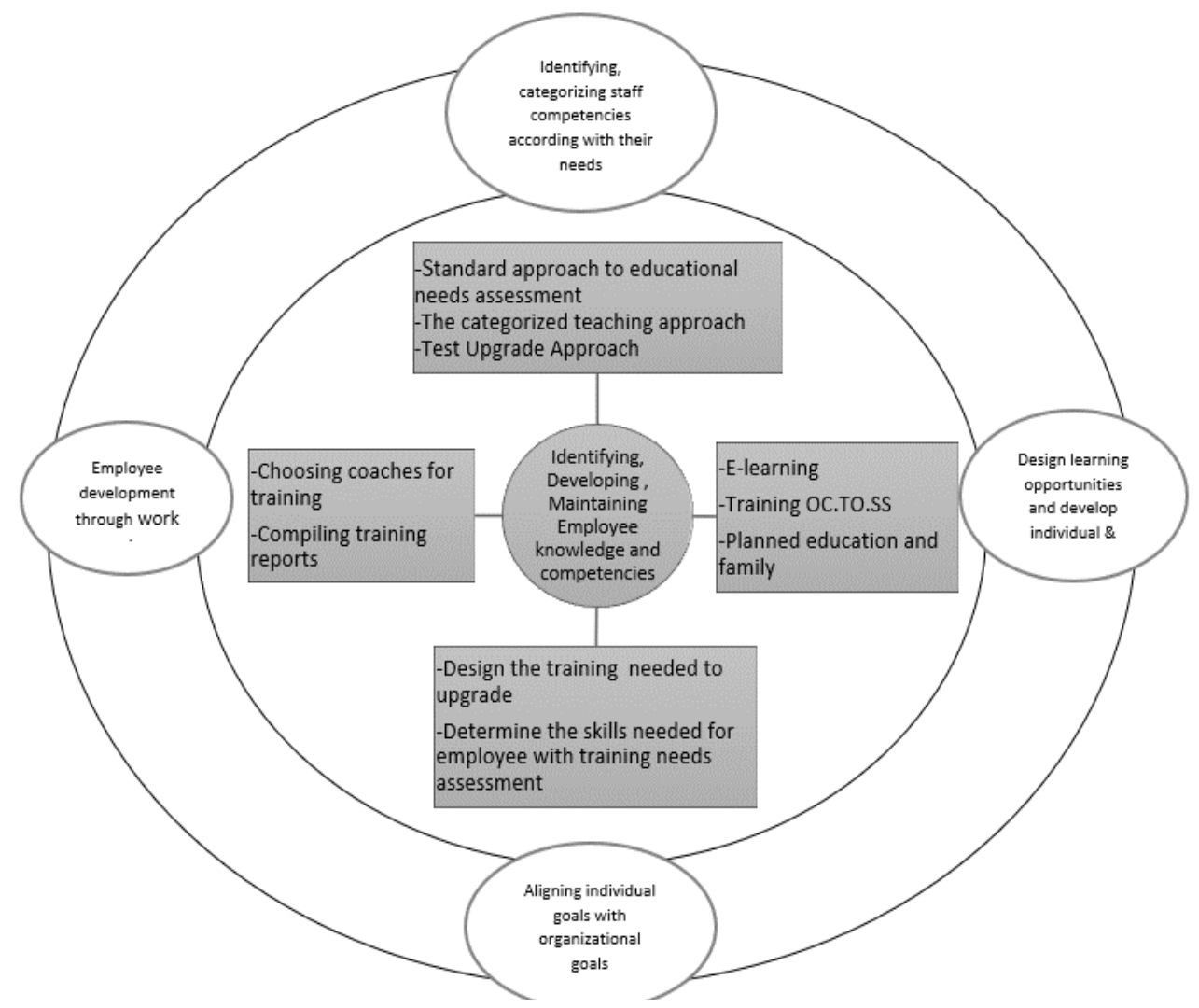

Fig. 3. Design model for evaluating organizational empowerment approaches according to the human resource dimension for the organization

\title{
5. Conclusion
}

Profitability in today's economic world lies and depends only on achieving a competitive advantage in the productions and service organizations. According to the result of this research paper, the competitive advantage must start and continue within the organization in all sections and based on inside of organizations. One of the factors cited in this study as contributing to the organization's success in global competitive advantage is the establishment of the EFQM Excellence 


\author{
(online) $=$ ISSN $2285-3642$ \\ ISSN-L = $2285-3642$ \\ Journal of Economic Development, Environment and People \\ Volume 9, Issue 2, 2020 \\ URL: http://jedep.spiruharet.ro \\ e-mail: office jedep@spiruharet.ro
}

Model. Establishing and applying an excellence EFQM model in organizations has many achievements and advantages, including the creation of competitive advantage and attention to customer demands and needs in all dimensions. The model consists of 9 criteria, five of which are empowerment-related, including leadership, policymaking, employees, partnerships, resources, and processes; and its 4 criteria relate to outcomes including, customer outcomes, employee outcomes, community outcomes, and key performance outcomes.

Organizational Excellence Models are effective tools when used properly, to achieve profitability, it is first necessary to strengthen and empower the organization capabilities' and abilities in various aspects, on the other hand, the results of the enablers become a premium service and optimal products for the customers. For the sustainable export and profitability, the organization environments' and the market at first must be identified and then start to create the new markets and attract other markets.

Of course, there are different ways to make organizations competitive, in this regard one of these mechanisms that lead to competition in the global dimension is to establish a model of excellence in organizations. The excellence model helps the organization's competitive advantage in two ways:

One is through empowerment, which is mainly related to the inside section of the organization, and it provides a platform for competitiveness and profitability in areas such as leadership, human resources, policies, resources, and processes of the organization. And the other one is through, it assesses and modifies the impact and outcomes of this empowerment on the dimensions of employees, customers, society, and overall performance outcomes. Therefore, establishing competitive advantage foundations and excellence models in the organization and then evaluate and assessing them based on the components mentioned in the article can achieve a competitive advantage for the organization in a wide and global scale.

\title{
6. Reference
}

[1] Achilov, Nurbek. "A New Marketing Paradigm for Creating Global Efficiency and Competitive Advantage of Countries." Journal of Accounting \& Marketing, vol. 05, no. 04, 2016, 10.4172/21689601.1000189.

[2] Alonso, Abel D. "Resources, Competitiveness, and Socioeconomic Development: The Case of a South American Emerging Economy." Local Economy: The Journal of the Local Economy Policy Unit, vol. 34, no. 1, Feb. 2019, pp. 68-87, 10.1177/0269094219829717. Accessed 2 Dec. 2019.

[3] Anderson, Erin, and Barton Weitz. "Determinants of Continuity in Conventional Industrial Channel Dyads." Marketing Science, vol. 8, no. 4, Nov. 1989, pp. 310-323, 10.1287/mksc.8.4.310. Accessed 5 Apr. 2020.

[4] Anjaningrum, Widiya Dewi, and Habel Rudamaga. "Creative Industry: Enhancing Competitive Advantage and Performance." Asia Pacific Management and Business Application, vol. 007, no. 03, 29 Apr. 2019, pp. 123-146, 10.21776/ub.apmba.2019.007.03.1. Accessed 19 Sept. 2019.

[5] Bell, Geoffrey. The Competitive Enterprise: 10 Principles of Business Excellence for Increas ed Market Share. London, Mcgraw-Hill, 2002.

[6] Berry, Leonard L. "Relationship Marketing of Services Perspectives from 1983 and 2000." Journal of 


\author{
(online) $=$ ISSN $2285-3642$ \\ ISSN-L = $2285-3642$ \\ Journal of Economic Development, Environment and People \\ Volume 9, Issue 2, 2020 \\ URL: http://jedep.spiruharet.ro \\ e-mail: office jedep@spiruharet.ro
}

Relationship Marketing, vol. 1, no. 1, Jan. 2002, pp. 59-77, 10.1300/j366v01n01_05. Accessed 25 July 2019.

[7] Brodie, Roderick J., et al. "Towards a Paradigm Shift in Marketing? An Examination of Current Marketing Practices." Journal of Marketing Management, vol. 13, no. 5, July 1997, pp. 383-406, 10.1080/0267257x.1997.9964481. Accessed 24 Apr. 2019.

[8] Cowen, Tyler, and Alexander Tabarrok. Modern Principles of Economics. New York Macmillan Education, 2018.

[9] de Berranger, Pascale, and Mary C. R. Meldrum. "The Development of Intelligent Local Clusters to Increase Global Competitiveness and Local Cohesion: The Case of Small Businesses in the Creative Industries." Urban Studies, vol. 37, no. 10, Sept. 2000, pp. 1827-1835, 10.1080/00420980020080441.

[10] D'Souza, Clare, and Mehdi Taghian. "Small and Medium Size Firm's Marketing Competitive Advantage and Environmental Initiatives in the Middle East." Journal of Strategic Marketing, vol. 26, no. 7, 4 May 2017, pp. 568-582, 10.1080/0965254x.2017.1318945. Accessed 24 Oct. 2019.

[11] Dubey, Ashish Mohan, et al. "Effective Implementation of Competitive Advantage and Sustainable Competitive Advantage: A Conceptual Model." International Journal of Business Innovation and Research, vol. 7, no. 5, 2013, p. 519, 10.1504/ijbir.2013.056176. Accessed 3 Mar. 2019.

[12] Dunning, John H, and Gavin Boyd. Alliance Capitalism and Corporate Management Entrepreneuri al Cooperation in Knowledge Based Economies. Cheltenham, Edward Elgar, 2003.

[13] Foss, Nicolai J, et al. Economic Organization, Capabilities and Co-Ordination : Essays in Honour of G.B. Richardson. London ; New York, Routledge, 2013.

[14] Grimm, Curtis M, et al. Strategy as Action Competitive Dynamics and Competitive Advantage . Oxford ; New York, Oxford University Press, 2006.

[15] Hamilton, Leslie, and Philip Webster. The International Business Environment. Oxford, United Kingdom, Oxford University Press, 2018.

[16] Huang, Kuo-Feng, et al. "From Temporary Competitive Advantage to Sustainable Competitive Advantage." British Journal of Management, vol. 26, no. 4, 13 May 2015, pp. 617-636, 10.1111/14678551.12104. Accessed 26 Feb. 2019.

[17] Jaccard, Michel. The Objective Is Quality: Introduction to Quality, Performance and Sustainability Management Systems. Boca Raton, Fla., London, 2013.

[18] Kaleka, Anna, and Neil A. Morgan. "Which Competitive Advantage(s)? Competitive Advantage-Market Performance Relationships in International Markets." Journal of International Marketing, vol. 25, no. 4, Dec. 2017, pp. 25-49, 10.1509/jim.16.0058. Accessed 3 Feb. 2019.

[19] Langlois, Richard N. "Business Organization and the Myth of the Market Economy." Journal of Economic Behavior \& Organization, vol. 23, no. 2, Mar. 1994, pp. 244-250, 10.1016/01672681(94)90072-8. Accessed 20 Nov. 2019.

[20] Petrylè, Vaiva. "DOES THE GLOBAL COMPETITIVENESS INDEX DEMONSTRATE THE RESILIENCE OF COUNTRIES TO ECONOMIC CRISES?" Ekonomika, vol. 95, no. 3, 11 Jan. 2017, p. 28, 10.15388/ekon.2016.3.10326. Accessed 18 Sept. 2019.

[21] Porter, Leslie J, and S J Tanner. Assessing Business Excellence : A Guide to Business Excellence and SelfAssessment. London, Routledge, 2013.

[22] Ruiz-Carrillo, Jose Ignacio Castresana, and Rubén Fernández-Ortiz. "Theoretical Foundation of the 


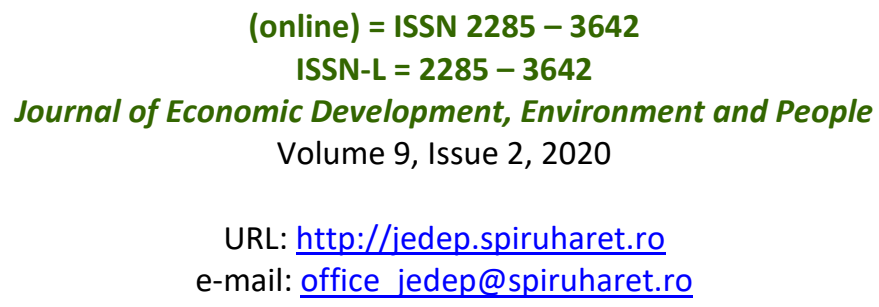

URL: http://jedep.spiruharet.ro e-mail: office jedep@spiruharet.ro

EFQM Model: The Resource-Based View." Total Quality Management \& Business Excellence, vol. 16, no. 1 , Jan. 2005, pp. 31-55, 10.1080/1478336042000309857.

[23] Rusjan, Borut. "Usefulness of the EFQM Excellence Model: Theoretical Explanation of Some Conceptual and Methodological Issues." Total Quality Management \& Business Excellence, vol. 16, no. 3, May 2005, pp. 363-380, 10.1080/14783360500053972.

[24] TOPTAŞ, Metin. "Neomodernism: Towards A Paradigm Shift In Marketing." TURKISH JOURNAL OF MARKETING, vol. 3, no. 2, 19 Aug. 2018, 10.30685/tujom.v3i2.40. Accessed 11 Nov. 2018.

[25] West, Douglas C, et al. Strategic Marketing: Creating Competitive Advantage . Oxford, Oxford University Press, 2015. 